\title{
PRINCIPLES OF PROPERTY INVESTMENT
}

AND PRICING 


\title{
PRINCIPLES OF PROPERTY INVESTMENT AND PRICING
}

\author{
W. D. Fraser, BSc, MSc, ARICS \\ Lecturer, The City University, London
}

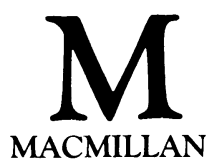


(C) W. D. Fraser 1984

Softcover reprint of the hardcover 1st edition 1984

All rights reserved. No part of this publication may be reproduced or transmitted, in any form or by any means, without permission

First published 1984 by

Higher and Further Education Division

MACMILLAN PUBLISHERS LTD

Houndmills, Basingstoke,

Hampshire, RG21 2XS,

and London

Companies and representatives

throughout the world

Typeset by Photo-Graphics, Honiton, Devon, England

British Library Cataloguing in Publication Data

Fraser, W. D.

Principles of property investment and pricing.

-(Macmillan building and surveying series)

1. Real estate investment

I. Title

332.63'24 HD1375

ISBN 978-0-333-32122-5 ISBN 978-1-349-17683-0 (eBook)

DOI 10.1007/978-1-349-17683-0 


\section{DEDICATION}

The content of this book evolved from my lectures to students in the B.Sc. Land Economics course at Paisley College from 1972-83. In return for their stoic endurance, I dedicate the book to them. 


\section{Contents}

Preface

Introduction

1

Property's place in the national economy; the structure of the book

PART I PRINCIPLES OF INVESTMENT AND ASSET PRICING

2 Debt and Equity - Risks and Returns

The risks and returns to debt and equity capital;

financial gearing and its significance; examples in

housing and corporate finance

3 Marketable Securities and the Stock Market

Going public; loan stock and ordinary shares compared; new issues; government bonds; the Stock Exchange, its functions and dealing mechanism; stock market investors

4 Analysis of Stock Market Securities

The aims of investment analysis; analysis of ordinary shares and corporate bonds; investment yields

5 Gilt Edged Securities - Prices and Yields

The impact of inflation and changing interest rates; the structure of yields; the impact of taxation; unconventional gilts

A model of share price determination; dividend yields, price volatility and growth 
The yield relationship between gilts and equities; preference shares and convertible stock; a summary of factors affecting yields

Efficient Market Theory, risk and portfolio theory; Modern Portfolio Theory, portfolio planning and management

$9 \quad$ Historic Trends in Stock Prices

Corporate profitability and the level of interest rates; the impact of the trade cycle and inflation; the 1973-4 stock market collapse and subsequent trends

PART II PROPERTY INVESTMENTS - PRICES AND YIELDS

Property interests and investment property types; characteristics of physical property; the property market and its imperfections

11 The Rental Yield and a Property Pricing Model

Property yields and the impact of rent review; a property pricing model

12 The Determination of Property Yields I

A comparison of property with stock market investments; investors' target IRR and growth expectation; the impact of depreciation; historical yield trends

13 The Determination of Property Yields II

Freehold and leasehold interests, the various property types, investment quality; applications of the price theory

\section{PART III THE DETERMINATION OF RENTAL VALUE}

The theory of economic rent and optimal factor combination; the relationship between economic rent and rental value 
Rental differences between properties; the general level of rental values; the occupation demand for business property; the supply of property for let, new and existing, long run and short run

16 Rental Value and Property Type

The determinants of the rental value of farmland, retail property, offices and industrial; relationship with macroeconomic trends

\section{PART IV THE THEORY AND FINANCE OF PROPERTY DEVELOPMENT}

\section{Site Values and Development Activity}

Development and the developer; risks and returns from property development; the theory of site value; obsolescence; cyclical trends in development activity; long-term trends in rental values

The developer's financial structure; the needs of the financier; sources of corporate finance; project finance, short term; long term; mortgage finance

19 Equity Sharing and Partnership Schemes

The rise of equity-sharing; sale and leasebacks, top/bottom and side-by-side schemes; partnerships with local authorities, lease and leaseback

\section{PART V PROPERTY INVESTORS AND PROPERTY PRICING}

The post-war growth of property companies; activities and functions; investment in property company shares

\section{The Financial Institutions}

General and long-term insurance companies; pension funds; their activities, functions and investment policy; property unit trusts; property bonds; managed bonds; charitable trusts; distribution of investment funds 
The case for investment overseas; criteria for selecting a country; the problems of overseas property investment; the impact of exchange controls

The pricing model reviewed; the impact of institutional investment policies; the case for property in the institutional portfolio; a supply and demand analysis

PART VI GOVERNMENT INTERVENTION IN THE PROPERTY MARKET

Aspects of Government Intervention in the Property

Market

The impact of planning control, rent control and land taxation; property as a tax shelter

\section{PART VII A POST-WAR HISTORY OF THE PROPERTY MARKET}

Traditional land ownership in Britain; the economic basis of the post-war boom; the development boom 1954-64; trends in the late 1960s

An analysis of the causes of the boom and bust, including the relationship between the property market and national economic trends, and the influence of the government and financial institutions

Market conditions since 1977 , the future for property investment

Questions for Discussion 


\section{Preface}

\section{Aim of the book}

The purpose of this book is to explain the determination of the value of business property (primarily shops, offices, industrial and agricultural), and its performance as an investment. It is thus a book about the economics of the property investment market. It examines the forces which determine value, and explains the relationship between macroeconomic trends and property values. It is intended to bridge the gap between the study of 'pure' economics and the practical knowledge that the property valuer or investor has of the market in which day to day operations take place.

The book explains how property values are determined, not how values are assessed, though it contains many implications for valuation practice. It explains the operation of the price mechanism in the property market, but makes no judgement on the efficiency of the system or about the justification for planning. It provides no solution to the problems of the urban economy, nor does it set out to explain patterns of urban land use, though incidentally it contains much of relevance to these subjects.

Although the book is written primarily as a student textbook, it is also intended for practitioners, even those whose education predates the introduction of discounted cash flow (DCF) analysis, and whose knowledge of algebra and economics has largely evaporated into the mists of time. Although an elementary knowledge of these subjects is beneficial, the principal theories and concepts are explained from first principles, and the mathematics and theoretical content has been reduced to the minimum considered essential for a thorough grasp of the subject. However, some passages will not be easy for those studying the subject for the first time, and when difficulty is encountered it is frequently best to read on and 
return later to the troublesome section. The reader should be prepared to read certain passages two or three times.

The author apologises for passages which are confusing, turgid or slow and for all errors and omissions. He humbly invites criticism.

The book is primarily designed for degree courses in estate management and land economics as well as for students preparing for the examinations of the Royal Institution of Chartered Surveyors. It should also prove valuable for experienced surveyors, especially those practising in the investment, development and valuation fields. The book will provide students and practitioners of town planning with a detailed insight into the economics of the property market, as well as providing an analysis appropriate for stockbrokers and investment analysts specialising in the property sector.

\section{Acknowledgements}

I would like to acknowledge with thanks the help given by the following: Professor Ivor Seeley for his comments on the text, Stephen Lumby for his suggestions and criticism of Part I, Dr Schiller of Hillier Parker for his comments on Part III and Mr John Orton and Gerald Brown of Richard Ellis. I would also like to thank the many firms which gave permission to publish their research material, in particular: Hillier Parker; Richard Ellis; Jones, Lang Wootton; Healey \& Baker; King \& Co.; Phillips \& Drew; de Zoete \& Bevan. Assistance was also gratefully received from Miles Larby of Bingham, Hughes \& Macpherson, John Nix of Wye College, Stewart Morley, Graeme Brown, Ken Barnett, Douglas Bodie, Bill Colville and Alex Culverwell. I am also indebted to Paisley College for the use of its facilities, and Professor Millington and the staff of the Land Economics Department. Finally, my thanks are due to Kathleen Ward who typed the manuscript with care and without complaint.

W. D. Fraser

Front cover photograph by kind permission of J. A. Story and Partners, Chartered Land Surveyors, Mitcham, Surrey. 